\title{
Nitrogen uptake capacity of European beech (Fagus sylvatica L.) only partially depends on tree age
}

\author{
Judy Simon ${ }^{1,3} \cdot$ Silvija Bilela $^{1} \cdot$ Heinz Rennenberg ${ }^{1,2}$ (i)
}

Received: 18 May 2021 / Accepted: 26 July 2021 / Published online: 9 August 2021

(C) The Author(s) 2021

\begin{abstract}
Key message On calcareous soil, European beech roots prefer organic nitrogen, but only arginine and not glutamine or inorganic nitrogen.

Abstract Nitrogen $(\mathrm{N})$ acquisition is a major factor determining the processes and mechanisms involved in tree productivity, development, and competitiveness. However, only few studies have investigated changes in $\mathrm{N}$ capturing with tree age. We conducted ${ }^{15} \mathrm{~N}$ incubation experiments to quantify inorganic (i.e. ammonium and nitrate) and organic (i.e. glutamine- $\mathrm{N}$ and arginine- $\mathrm{N}$ ) net $\mathrm{N}$ acquisition capacity of beech trees of five age classes. Our results showed no general pattern, but that net $\mathrm{N}$ uptake capacity was rather $\mathrm{N}$ source-specific. Inorganic and glutamine- $\mathrm{N}$ uptake did not differ between age classes at all. Arginine-N uptake was highest in the youngest and oldest stands reflecting a high $\mathrm{N}$ demand by seedlings for root foraging and biomass production despite low internal $\mathrm{N}$ storage capacities and by older trees for storage and reproduction. Organic $\mathrm{N}$ was preferred over inorganic $\mathrm{N}$ regardless of tree age. Overall, our study shows the high significance of organic $\mathrm{N}$ sources for $\mathrm{N}$ acquisition in beech trees.
\end{abstract}

Keywords Ammonium $\cdot$ Nitrate $\cdot$ Glutamine $\cdot$ Arginine $\cdot$ Nitrogen uptake

\section{Introduction}

The capacity to capture resources, particularly nitrogen $(\mathrm{N})$, plays an important role in achieving maximum growth in long-living woody species (Körner, 2003; Millard et al. 2007; Millard and Grelet, 2010). Particularly in deciduous trees, growth depends on both external uptake of $\mathrm{N}$ from the soil, but also internal N pools (Millard, 1996; Dyckmans and Flessa, 2001) and is regulated by the internal storage

Communicated by Arthur Gessler .

Judy Simon

judy.simon@uni-konstanz.de

1 Chair of Tree Physiology, Institute of Forest Sciences, University of Freiburg, Georges-Köhler-Allee 53/54, 79110 Freiburg, Germany

2 Center of Molecular Ecophysiology (CMEP), College of Resources and Environment,, Southwest University, No. 2, Tiansheng Road, Beibei District, Chongqing 400715, P.R. China

3 Present Address: Plant Interactions Ecophysiology Group, Department of Biology, University of Konstanz, Universitätsstrasse 10, 78457 Konstanz, Germany capacity (Tagliavini et al. 1997; Rennenberg et al. 2010). For example, more $\mathrm{N}$ is taken up by seedlings at the beginning of the growing season because $\mathrm{N}$ demand is high and internal $\mathrm{N}$ storage capacity is low due to a restricted storage capacity and the use of internal resources for leaf development (Fotelli et al. 2004; Simon et al. 2011). Overall, the resource capturing capacity of a tree is regulated by its size which in turn is linked to its age via the accumulation during past growth (e.g. Millard and Grelet, 2010; Aakala et al. 2013; De Groote et al. 2018). However, studies on agerelated effects are scarce and mostly based on the stand level including tree productivity (Olsen et al. 1998; Portsmuth et al. 2005; De Groote et al. 2018) and/or soil properties (Staska et al. 2014; Wang et al. 2017).

$\mathrm{N}$ acquisition is a key aspect in understanding the processes and mechanisms leading to high productivity and competitiveness, but only few studies have investigated shifts in $\mathrm{N}$ capturing strategies (i.e. via external acquisition or internal remobilisation of $\mathrm{N}$ ) with increasing age at the individual tree level (Simon et al. 2011; Sun et al. 2016). Thus, the influence of tree age on $\mathrm{N}$ acquisition from the soil is still not fully understood (Liu et al. 2018). For example, with increasing tree age, root morphology and physiology 
are likely to change as younger individuals require and allocate more $\mathrm{N}$ to increase root length and surface area for better root foraging (Saulnier and Reekie, 1995; Ryan et al, 1997; Liu et al. 2018). Furthermore, with increasing age more $\mathrm{N}$ is stored in the heartwood of trees and their litter, thus overall soil $\mathrm{N}$ availability might be reduced over time during forest development (Ryan et al. 1995).

This study builds on previous work investigating the uptake capacity of seedlings and adult individuals of Fagus sylvatica for inorganic and organic $\mathrm{N}$ over the growing season (Simon et al. 2011). Here, we hypothesise that the acquisition of inorganic and organic $\mathrm{N}$ resources from the soil decreases with tree age as tree internal storage capacity and, thus, remobilisation from storage pools rise (Simon et al. 2011). We investigated five forest stands differing in age at a site on calcareous soil. We chose European beech as a model species, because it represents the potential natural vegetation in moist to moderately dry areas of the submountainous altitude range in Central Europe (Ellenberg and Leuschner, 2014) and has been favoured by forest practitioners (Petritan et al. 2009; Simon et al. 2011) despite its sensitivity to drought (Geßler et al. 2007; Houston et al. 2016).

\section{Materials and methods}

\section{Field site characteristics and experimental design}

The study was conducted in beech-dominated forest stands of different age classes at the "Schönberg" (department "Leisacker" and "Baumgarten") in Freiburg im Breisgau in southern Germany $\left(47^{\circ} 57^{\prime} \mathrm{N}, 7^{\circ} 48^{\prime} \mathrm{O}, 645 \mathrm{~m}\right.$ above sea level). The soil is a rendzina on calcareous parent rock with a high $\mathrm{pH}$ and a low water holding capacity (Körner, 2006). Hädrich and Stahr, 2001 reported $0.79-1.05 \%$ total soil N in the Ah horizon (ranging from 0 to $15 \mathrm{~cm}$ depth) which is similar to that of other beech forests on calcareous soil (see Pena et al. 2010: 0.8\% total soil N). Mean annual temperature and precipitation were $11.4{ }^{\circ} \mathrm{C}$ and $934 \mathrm{~mm}$, respectively, at the weather station Freiburg (\#1443, 48.0232, 7.8344; 236 m a. s. 1.; 1981-2010, Deutscher Wetterdienst
DWD). Sites were set up in stands of different European beech (Fagus sylvatica L.) age classes with three replicate plots per age class. Per plot and age class, ${ }^{15} \mathrm{~N}$ incubation experiments were performed on 5-8 individual beech trees (with a total of 15-24 individuals per age class). At the sampling time, the five age classes included e $1-5$ to 10 years, e2 -12 to 25 years, e3-23 to 31 years, e5-43 to 65 years, and e12-85 to 130 years old beech trees (see Table 1). Forests stands were beech-dominated, except for age class e2 were Fagus sylvatica was mixed with few individuals of Acer pseudoplatanus L., Prunus avium L., and Fraxinus excelsior $\mathrm{L}$. of similar age. For each plot, soil samples were taken from top soil (max. $10 \mathrm{~cm}$ depth) at five different locations and pooled. Subsamples were sieved, dried at $60^{\circ} \mathrm{C}$ for $72 \mathrm{~h}$. Total $\mathrm{N} \%$ was quantified using an elemental analyser (see below).

\section{${ }^{15} \mathrm{~N}$ uptake experiments}

${ }^{15} \mathrm{~N}$ uptake experiments were conducted in autumn before leaf senescence. To quantify inorganic and organic net $\mathrm{N}$ uptake capacity by mycorrhizal fine roots, we used the ${ }^{15} \mathrm{~N}$ enrichment technique described by Gessler et al. (1998) as modified by Simon et al. (2010a). For this purpose, fine roots still attached to the individual trees were carefully dug out and cleaned of adherent soil material using tap water. Five root tips (c. $40-60 \mathrm{mg}$ each) were incubated individually in $4 \mathrm{ml}$ of one of five artificial soil solutions for $2 \mathrm{~h}$. The artificial soil solution was modelled as previously reported for another field site on calcareous soil (Gessler et al. 2005; Simon et al. 2011) and contained four different $\mathrm{N}$ sources one of which was ${ }^{15} \mathrm{~N} /{ }^{13} \mathrm{C}$-labelled (i.e. ammonium, nitrate, glutamine, or arginine; all with $>97 \%$ enrichment) or without label (i.e. to account for natural abundance). Overall, the solution contained $90 \mu \mathrm{M} \mathrm{CaCl}_{2} * 2 \mathrm{H}_{2} \mathrm{O}, 70 \mu \mathrm{M} \mathrm{MgCl}_{2}$ * $6 \mathrm{H}_{2} \mathrm{O}, 50 \mu \mathrm{M} \mathrm{KCl}, 24 \mu \mathrm{M} \mathrm{MnCl}_{2} * 4 \mathrm{H}_{2} \mathrm{O}, 20 \mu \mathrm{M} \mathrm{NaCl}$, $10 \mu \mathrm{M} \mathrm{AlCl}, 3 \mu \mathrm{M} \mathrm{FeSO}_{4} * 7 \mathrm{H}_{2} \mathrm{O}, 6 \mu \mathrm{M} \mathrm{K}_{2} \mathrm{HPO}_{4}, 100 \mu \mathrm{M}$ $\mathrm{KNO}_{3}$, and $1 \mu \mathrm{M} \mathrm{NH} \mathrm{H}_{4} \mathrm{Cl}$, as well as the amino acids glutamine (Gln) and arginine (Arg) (both $25 \mu \mathrm{M}$ ). Gln and Arg were chosen as amino acids because they are the most abundant amino acids in European beech roots (Stoelken
Table 1 Field site description. Age class, age range (years), tree diameter at breast height $(\mathrm{DBH}, \mathrm{cm})$, presence of other tree species, total $\mathrm{N}$ in soil (\%), and total $\mathrm{N}$ in the fine roots (\%)

\begin{tabular}{llllll}
\hline Class & Age & DBH & In plots mixed with & $N$ in soil & $N$ in fine roots \\
\hline e1 & $5-10$ & $2.9 \pm 1.0$ & n.a & $0.25 \pm 0.01^{\mathrm{a}}$ & $0.95 \pm 0.20^{\mathrm{a}}$ \\
e2 & $12-25$ & $9.0 \pm 3.1$ & $\begin{array}{c}\text { Acer pseudoplatanus, Prunus } \\
\text { avium, Fraxinus excelsior }\end{array}$ & $0.42 \pm 0.01^{\mathrm{b}}$ & $0.87 \pm 0.16^{\mathrm{a}}$ \\
& & & $0.40 \pm 0.01^{\mathrm{b}}$ & $1.16 \pm 0.21^{\mathrm{bc}}$ \\
e3 & $23-31$ & $12.7 \pm 2.3$ & n.a & $0.50 \pm 0.03^{\mathrm{c}}$ & $1.27 \pm 0.25^{\mathrm{b}}$ \\
e5 & $43-65$ & $23.0 \pm 3.8$ & n.a & $0.47 \pm 0.01^{\mathrm{c}}$ & $1.01 \pm 0.17^{\mathrm{ac}}$ \\
e12 & $85-130$ & $43.0 \pm 10.0$ & Very few Abies alba &
\end{tabular}

Different letters indicate significant differences between age classes $(p \leq 0.050)$ n.a. not applicable 
et al. 2010) and also represent dominant amino acids in forest soil (Inselsbacher et al. 2011). The amino acid concentration used was within the range of estimates previously reported (Inselsbacher et al. 2011). Incubation experiments were conducted between 10 am and $2 \mathrm{pm}$ to avoid diurnal variation of $\mathrm{N}$ uptake (Gessler et al. 2002). After $2 \mathrm{~h}$ of incubation, the submersed root tips were cut off, washed in $0.5 \mu \mathrm{M} \mathrm{CaCl}{ }_{2}$ to remove excess ${ }^{15} \mathrm{~N}$ on the surface and dried with cellulose tissue. After determining the fresh weight, the root samples were oven-dried $\left(48 \mathrm{~h}\right.$ at $\left.60{ }^{\circ} \mathrm{C}\right)$ and the dry weight was recorded. Dry root material was ground to a fine homogenous powder using a ball mill and prepared for isotope ratio mass spectrometry.

\section{Quantification of ${ }^{15} \mathrm{~N},{ }^{13} \mathrm{C}$, and total $\mathrm{N}$ and $\mathrm{C}$ amounts in fine roots}

For the quantification of ${ }^{15} \mathrm{~N},{ }^{13} \mathrm{C}$, as well as total $\mathrm{N}$ and $\mathrm{C}$ amounts in the fine roots of beech trees of different age classes, aliquots of 1.2-2.5 mg homogenous root powder were weighed into tin capsules (4-6 mm, IVA Analysentechnik, Meerbusch, Germany) and analysed using an elemental analyser (NA2500, CE Instruments, Milan, Italy) coupled via a Conflo II interface to an isotope ratio mass spectrometer (Delta Plus, Thermo Finnigan MAT GmbH, Bremen, Germany). Glutamic acid was analysed as working standard after every $12^{\text {th }}$ sample to detect potential instrument drift over time. This standard was calibrated against the primary standards USGS $25\left(d^{15} \mathrm{~N}_{\text {air }}=-30.4\right)$ and USGS 41 $\left(d^{15} \mathrm{~N}_{\text {air }}=47.600\right)$ for ${ }^{15} \mathrm{~N}$ and USGS $40\left(d^{13} \mathrm{C}_{\mathrm{PDB}}=-26.39\right)$ and USGS $41\left(d^{13} C_{\text {PDB }}=37.63\right)$ for ${ }^{13} \mathrm{C}$. Inorganic and organic net $\mathrm{N}$ uptake capacity was calculated based on the incorporation of ${ }^{15} \mathrm{~N}$ into the fresh root biomass according to the equation reported by Gessler et al. (1998): net $\mathrm{N}$ uptake capacity $=\left(\left({ }^{15} \mathrm{~N}_{1}-{ }^{15} \mathrm{~N}_{\mathrm{n}}\right) * \mathrm{~N}_{\text {tot }} * \mathrm{dw} * 10^{5}\right) /(\mathrm{MW} * \mathrm{fw} * t)$, where ${ }^{15} \mathrm{~N}_{1}$ and ${ }^{15} \mathrm{~N}_{\mathrm{n}}$ are the atom $\%$ of ${ }^{15} \mathrm{~N}$ in labelled $\left(\mathrm{N}_{1}\right)$ and non-labelled $\left(\mathrm{N}_{\mathrm{n}}\right.$, natural abundance) roots, respectively, $\mathrm{N}_{\text {tot }}$, is total $\mathrm{N}$ percentage, "MW is the molecular weight of ${ }^{15} \mathrm{~N}$ and $t$ represents the incubation time $(120 \mathrm{~min}){ }^{1} .{ }^{13} \mathrm{C}$ net uptake capacity of Gln and Arg was generally lower compared to those based on ${ }^{15} \mathrm{~N}$ suggesting (1) a potential degradation of Gln and Arg during the incubation in the artificial soil solution and/or on the root surface and/or (2) the respiration of amino acid-derived carbon inside the roots (Simon et al. 2011).

\section{Statistical analyses}

Data were tested for normality (Shapiro-Wilk test) and equal variances (Brown-Forsythe test). Differences in soil $\mathrm{N} \mathrm{lev-}$ els between age classes were tested by one-way ANOVA followed by the post hoc Holm-Sidak test. Kruskal-Wallis oneway ANOVA on Ranks followed by post hoc Dunn's test was performed to test for (1) the effect of age class on each $\mathrm{N}$ source (i.e. ammonium, nitrate, glutamine-N, and arginine$\mathrm{N}$ ), (2) the preference for certain $\mathrm{N}$ sources within each age class, and (3) total soil $\mathrm{N}$ and $\mathrm{C}$ in the fine roots between age classes. Significant differences were tested at $p \leq 0.050$ using Sigmaplot 13.0 (Systat Software Inc., San Jose, CA, USA).

\section{Results and discussion}

\section{Total soil $\mathbf{N}$ increases with tree age}

Soil $\mathrm{N}$ levels might decline with stand age because of the accumulation of $\mathrm{N}$ in tree biomass and immobilisation during wood decomposition (Murty et al. 1996; Gover et al. 1996; Ryan et al. 1997). However, studies investigating the mineralisation rates of nutrients in forest chronosequences found no general pattern (Ryan et al. 1997). In our study, total soil $\mathrm{N}$ levels significantly increased with stand age, i.e. age classes e 12 and e $5>\mathrm{e} 3$ and e $2>\mathrm{e} 1(p \leq 0.003)$, and varied from $0.25 \%$ in the youngest to $0.47 \%$ in the oldest age class (Table 1). These levels are between those measured at the research stations with beech forest on calcareous soil in Tuttlingen, Germany (on average $0.80 \pm 0.01$ total $\mathrm{N} \%$ in the top soil; Pena et al. 2010) and acidic soil in the Höglwald, Germany (on average $0.23 \pm 0.05$ total $\mathrm{N} \%$ in the top soil; Stoelken et al. 2010). Total $\mathrm{N}$ levels in the soil did not reflect the levels in the fine roots which is likely due the unavailability of some $\mathrm{N}$ pools in the soil for root acquisition, for example $\mathrm{N}$ immobilised by soil microbes (Simon et al. 2017). In our study, total $\mathrm{N}$ levels in fine roots were higher for the middle-aged trees compared to the youngest and oldest (i.e. age class e $3>\mathrm{e} 1$ and e2, as well as e5 $>\mathrm{e} 1$, $\mathrm{e} 2$ and e12; $p \leq 0.045$; Table 1). Total $\mathrm{C}$ levels of the fine roots ranged from $44.68 \pm 5.41$ total $\mathrm{C} \%$ in the youngest to $42.21 \pm 4.28$ total $\mathrm{C} \%$ in the oldest forest stand and did not differ between age classes. High $\mathrm{N}$ levels are required for root growth and development to enhance the foraging capacities, especially in seedlings (Chapin et al. 1994; Saulnier and Reekie; Liu et al. 2018), further $\mathrm{N}$ is also required in mature trees for reproduction (Chapin et al. 1994; Saulnier and Reekie, 1995). Soil N levels between young and adult beech trees were not different in the study by Simon et al. (2011) which could be explained by age differences between the studies (i.e. seedling age was comparable to that in our study, whereas the age of the adult trees was between e5 and e12).

\section{Patterns of $\mathbf{N}$ acquisition with increasing tree age are source-specific}

The comparison of inorganic and organic $\mathrm{N}$ uptake capacity among the five investigated age classes in our study showed no general pattern, but was rather $\mathrm{N}$ source-specific. 

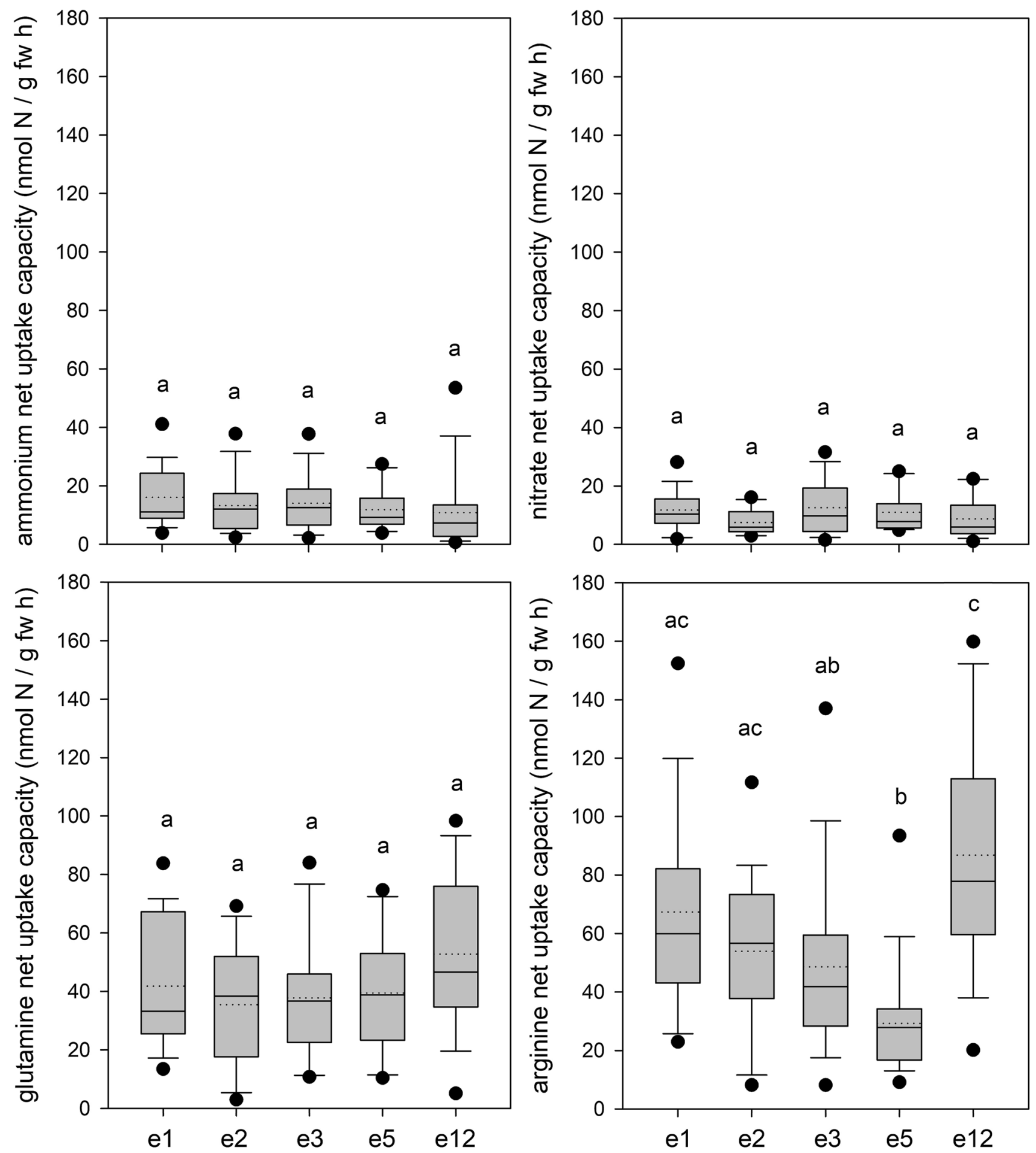

Fig. 1 Ammonium, nitrate, glutamine-N, and arginine-N net uptake capacity $(\mu \mathrm{mol} \mathrm{N} / \mathrm{g} \mathrm{fw} \mathrm{h})$ of the fine roots of European beech at five different age classes. e1 $=5-10$ years, e2 $=12-25$ years, e $3=23-31$ years, e $5=43-65$ years, and e $12=85-130$ years. Box

Ammonium, nitrate, and glutamine-N net uptake capacity did not differ at all among age classes, whereas arginine-N net uptake capacity was higher in the two youngest and the oldest stands compared to the middle-aged stands: e1, e2,

plots show mean (dotted line) and median (straight line). Different letters indicate significant differences among age classes within a specific N source $(p<0.050)$

e12 > e5 ( $p \leq 0.049)$, and e12> e3 ( $p=0.012$; Fig. 1, Supplemental Table 1). These results differ from those in the two other studies that looked at changes in inorganic and organic $\mathrm{N}$ acquisition in trees with age. Liu et al. (2018) studied $\mathrm{N}$ 
uptake in Hevea brasiliensis (rubber tree) plantations and found that with increasing tree age glycine uptake increased, whereas ammonium uptake decreased. Simon et al. (2011) compared $\mathrm{N}$ acquisition of seedlings and adult beech trees over the growing season: both net nitrate and glutamine$\mathrm{N}$ uptake capacity were higher in mature beech compared to seedlings, whereas net ammonium uptake capacity did not differ (Simon et al. 2011). However, the studied trees of different age in Simon et al. (2011) were within the same stand indicating seasonal avoidance of potential competition between seedlings and mature trees, whereas in the current study age classes were in strictly separated forest stands. Furthermore, differences in the uptake of specific amino acids might be related to their abundance in the soil (Simon et al. 2017). Especially positively charged amino acids, such as arginine, are likely to dominate soil diffuse $\mathrm{N}$ fluxes when released during the degradation of microbial and/or plant tissue which could then affect the expression of the relevant arginine transporters in plants (Inselsbacher and Wanek, 2021), and thus their N uptake capacity. Mycorrhiza might have an additional effect on a tree's $\mathrm{N}$ acquisition strategy as mycorrhizal community composition might change with tree age. However, a previous study on mycorrhiza and beech seedlings found that organic $\mathrm{N}$ uptake occurs regardless of mycorrhization (Stoelken et al. 2010). Furthermore, Leberecht et al. (2016) showed that ectomycorrhiza preferred ammonium, whereas beech preferred nitrate, thus avoiding competition for the same inorganic $\mathrm{N}$ sources. How this plays out for organic $\mathrm{N}$ sources and/or shifts with increasing tree age is still unknown.

The $\mathrm{N}$ conservation strategy of trees is regulated by its $\mathrm{N}$ uptake and storage capacities as well as the availability of $\mathrm{N}$ in the soil (Reich et al. 1997; Sun et al. 2016; Simon et al. 2017). In our study, arginine-N uptake capacity was higher in youngest and oldest trees, confirming our initial hypothesis that younger trees take up more $\mathrm{N}$ from the soil due to their low internal N storage capacity (e.g. Millard and Grelet, 2010; Simon et al. 2011; Sun et al. 2016) most likely via a higher uptake capacity for N. The higher arginine-N acquisition by beech trees in the oldest stand compared to the middle-aged trees contradicts our initial hypothesis that older trees take up less $\mathrm{N}$ from the soil as they rely more on internal $\mathrm{N}$ remobilisation from storage (e.g. Millard and Grelet, 2010; Simon et al. 2011). However, effective $\mathrm{N}$ acquisition from the soil might differ from the capacity of roots to take up $\mathrm{N}$ and is likely related to the relative abundance of different $\mathrm{N}$ forms (Inselsbacher and Wanek, 2021). Furthermore, the amino acids used in this study have different functions within plants: glutamine is the main amino acid transported in beech, whereas arginine is a storage amino acid (Millard and Grelet, 2010; Babst and Coleman, 2018). Thus, considering the abundance of specific $\mathrm{N}$ forms in the soil as well as the shift in a tree's demand for $\mathrm{N}$ over its lifetime, this might also lead to changes in $\mathrm{N}$ acquisition strategy. For example, at the seedling stage, trees require more $\mathrm{N}$ to increase root foraging for growth and biomass production and the use of enhanced storage capacity, whereas mature trees need N for reproduction (Chapin et al. 1994; Saulnier and Reekie, 1995) with a potentially declining nitrogen use efficiency (Ryan et al. 1997).

\section{General preference for organic over inorganic N sources over all age classes}

Comparing inorganic and organic $\mathrm{N}$ uptake capacity within each age class, net uptake capacity of organic $\mathrm{N}$ was generally higher than that of inorganic $\mathrm{N}(p \leq 0.019)$. These results confirm previous studies quantifying inorganic and organic net $\mathrm{N}$ uptake capacity of adult beech and/or beech seedlings under controlled conditions and in the field that were incubated with an artificial $\mathrm{N}$ solution of the same composition: beech trees generally preferred organic over inorganic $\mathrm{N}$, and nitrate over ammonium (see Supplemental Table 1). These patterns were found regardless of age (i.e. mature beech vs. seedlings, Simon et al. 2011), species (i.e. Simon et al. 2010; Dong et al. 2016; Li et al. 2016), abiotic (e.g. light availability; Simon et al. 2014) as well as biotic factors (e.g. competition with sycamore maple; Simon et al. 2010; Li et al. 2016).

In conclusion, tree age or rather its developmental stage does have some effect on the acquisition of inorganic and organic $\mathrm{N}$ sources from the soil depending on plant internal factors, such as its $\mathrm{N}$ demand and internal storage capacities, but also abiotic factors such as the abundance of specific $\mathrm{N}$ sources which in turn might regulate the expression of genes encoding $\mathrm{N}$ transporters.

Author contribution statement JS and HR conceived and designed the study. JS and SB conducted the ${ }^{15} \mathrm{~N}$ uptake experiments at the field sites. SB prepared the samples for IRMS analysis and performed pre-statistical data processing. JS statistically analysed the data and wrote the initial draft of the manuscript. All authors contributed to manuscript revisions and approved the final manuscript.

Supplementary Information The online version contains supplementary material available at https://doi.org/10.1007/s00468-021-02190-z.

Acknowledgements We thank Fang Dong, Xiuyuan Li, Chajuan $\mathrm{Guo}$, and $\mathrm{Bin} \mathrm{Hu}$ for their assistance in the field. We also thank the Städtisches Forstamt Freiburg for providing the sites of this study.

Funding Open Access funding enabled and organized by Projekt DEAL. This work was supported by the German Research Foundation, Beech Research Group FOR 788. JS is currently supported by a Heisenberg Fellowship (no. SI 1556/4-1) of the German Research Foundation (DFG). 
Data availability Data will be available from the Dryad Digital Repository upon acceptance of the manuscript.

Code availability Not applicable.

\section{Declarations}

Conflict of interest None declared.

Open Access This article is licensed under a Creative Commons Attribution 4.0 International License, which permits use, sharing, adaptation, distribution and reproduction in any medium or format, as long as you give appropriate credit to the original author(s) and the source, provide a link to the Creative Commons licence, and indicate if changes were made. The images or other third party material in this article are included in the article's Creative Commons licence, unless indicated otherwise in a credit line to the material. If material is not included in the article's Creative Commons licence and your intended use is not permitted by statutory regulation or exceeds the permitted use, you will need to obtain permission directly from the copyright holder. To view a copy of this licence, visit http://creativecommons.org/licenses/by/4.0/.

\section{References}

Aakala T, Fraver S, D’Amato AW et al (2013) Influence of competition and age on tree growth in structurally complex old-growth forests in northern Minnesota, USA. For Ecol Manag 308:128-135. https://doi.org/10.1016/j.foreco.2013.07.057

Babst BA, Coleman GD (2018) Seasonal nitrogen cycling in temperate trees: transport and regulatory mechanisms are key missing links. Plant Sci 270:268-277. https://doi.org/10.1016/j.plantsci. 2018.02.021

Chapin FS, Walker LR, Fastie CL et al (1994) Mechanisms of primary succession following deglaciation at Glacier Bay, Alaska. Ecol Monogr 64:149-175. https://doi.org/10.2307/2937039

De Groote SRE, Vanhellemont M, Baeten L et al (2018) Competition, tree age and size drive the productivity of mixed forests of pedunculate oak, beech and red oak. For Ecol Manag 430:609-617. https://doi.org/10.1016/j.foreco.2018.8.050

Dong F, Simon J, Rienks M et al (2016) Environmental effects on soil NO concentration and root $\mathrm{N}$ uptake in beech and spruce forests. J Plant Nutr Soil Sci 179:244-256. https://doi.org/10.1002/jpln. 201500191

Dyckmans J, Flessa H (2001) Influence of tree internal N status on uptake and translocation of $\mathrm{C}$ and $\mathrm{N}$ in beech: a dual ${ }^{13} \mathrm{C}$ and ${ }^{15} \mathrm{~N}$ labelling approach. Tree Physiol 21:395-401. https://doi.org/10. 1093/treephys/21.6.395

Ellenberg H, Leuschner C (2014) Vegetation Mitteleuropas mit den Alpen in ökologischer, dynamischer und historischer Sicht, 6th edn. Ulmer Verlag, Stuttgart, Germany

Fotelli MN, Rienks M, Rennenberg H et al (2004) Climate and forest management affect ${ }^{15} \mathrm{~N}$-uptake, $\mathrm{N}$ balance and biomass of European beech seedlings. Trees 18:157-166. https://doi.org/10.1007/ s00468-003-0289-4

Gessler A, Schneider S, von Sengbusch D et al (1998) Field and laboratory experiments on net uptake of nitrate and ammonium by the roots of spruce (Picea abies) and beech (Fagus sylvatica) trees. New Phytol 138:275-285. https://doi.org/10.1046/j.1469-8137. 1998.00107.x

Gessler A, Kreuzwieser J, Dopatka T et al (2002) Diurnal courses of ammonium net uptake by the roots of adult beech (Fagus sylvatica) and spruce (Picea abies) trees. Plant Soil 240:23-32. https://doi.org/10.1023/A:1015831304911

Gessler A, Jung J, Gasche R et al (2005) Climate and forest management influence nitrogen balance of European beech forests: microbial $\mathrm{N}$ transformations and inorganic $\mathrm{N}$ net uptake capacity of mycorrhizal roots. Eur J for Res 124:95-111. https://doi.org/ 10.1007/s10342-005-0055-9

Geßler A, Keitel C, Kreuzwieser J et al (2007) Potential risks for European beech (Fagus sylvatica L.) in a changing climate. Trees 21:1-11. https://doi.org/10.1007/s00468-006-0107-x

Gover ST, McMurtie RE, Murty D (1996) Aboveground net primary productivity decline with stand age: potential causes. Trends Ecol Evol 11:378-382. https://doi.org/10.1016/0169-537(96)10042-2

Hädrich F, Stahr K (2001) Die Böden des Breisgaus und angrenzender Gebiete. Berichte der Naturforschenden Gesellschaft Freiburg im Breisgau 91, Freiburg im Breisgau, Germany

Houston T, de Rigo D, Caudullo G (2016) Fagus sylvatica and other beeches in Europe: distribution, habitat, usage and threats. In: San-Miguel-Ayanz J, de Rigo D, Caudullo G, Houston T, Mauri A (eds) European atlas of forest tree species. Publication office of the European Union, Luxembourg, pp 94-95

Inselsbacher E, Öhlund J, Jämtgard S et al (2011) The potential of microdialysis to monitor organic and inorganic nitrogen compounds in soil. Soil Biol Biochem 43:1321-1332. https://doi.org/ 10.1016/j.soilbio.2011.03.003

Inselsbacher E, Wanek W (2021) An unexpected source of nitrogen for root uptake: positively charged amino acids dominate soil diffusive nitrogen fluxes. New Phytol. https://doi.org/10.1111/nph. 17315

Körner C (2003) Carbon limitation in trees. J Ecol 91:4-17. https://doi. org/10.1046/j.1365-2745.2003.00742.x

Körner H (2006) Der Schönberg - Natur- und Kulturgeschichte eines Schwarzwald-Vorberges, 1st edn. Lavori Verlag, Freiburg im Breisgau, Germany

Leberecht M, Dannenmann M, Tejedor J, Simon J, Rennenberg H, Polle A (2016) Segregation of nitrogen use between ammonium and nitrate of ectomycorrhizas and beech trees. Plant Cell Environ 39:2691-2700. https://doi.org/10.1111/pce.12820

Li X, Rennenberg H, Simon J (2016) Seasonal variation in N uptake strategies in the understorey of a beech-dominated N-limited forest ecosystem depends on $\mathrm{N}$ source and species. Tree Physiol 36:589-600. https://doi.org/10.1093/treephys/tpv132

Liu M, Xu F, Xu X et al (2018) Age alters uptake pattern of organic and inorganic nitrogen by rubber trees. Tree Physiol 38:1685-1693. https://doi.org/10.1093/treephys/tpy031

Millard P (1996) Ecophysiology of the internal cycling of nitrogen for tree growth. Z Pflanz Bodenkunde 159:1-10. https://doi.org/10. 1002/jpln.1996.3581590102

Millard P, Sommerkorn M, Grelet G-A (2007) Environmental change and carbon limitation in trees: a biochemical ecophysiological and ecosystem appraisal. New Phytol 175:11-28. https://doi.org/10. 1111/j.1469-8137.2007.02079.x

Millard P, Grelet G-A (2010) Nitrogen storage and remobilization by trees: ecophysiological relevance in a changing world. Tree Physiol 30:1083-1095. https://doi.org/10.1093/treephys/tpq042

Murty D, McMurtie RE, Ryan MG (1996) Declining forest productivity in ageing forest stands-a modeling analysis of alternative hypotheses. Tree Physiol 16:187-200. https://doi.org/10.1093/ treephys/16.1-2.187

Olsen U, Binkley D, Smith FW (1998) Nitrogen supply, nitrogen use, and production in an age sequence of lodgepole pine. For Sci 44:454-457. https://doi.org/10.1093/forestscience/44.3.454

Pena R, Offermann C, Simon J et al (2010) Girdling affects ectomycorrhizal fungal (EMF) diversity and reveals functional differences in 
EMF community composition in a beech forest. Appl Env Microbiol 76:1831-1841. https://doi.org/10.1128/AEM.01703-09

Petritan AM, von Lüpke B, Petritan IC (2009) Influence of light availability on growth, leaf morphology and plant architecture of beech (Fagus sylvatica L.), maple (Acer pseudoplatanus L.) and ash (Fraxinus excelsior L.) saplings. Eur J for Res 128:61-74. https:// doi.org/10.1007/s10342-008-0239-1

Portsmuth A, Niinemets Ü, Truus L et al (2005) Biomass allocation and growth rates in Pinus sylvestris are interactively modified by nitrogen and phosphorus availabilities and by tree size and age. Canad J for Res 35:2346-2359. https://doi.org/10.1139/X05-155

Reich PB, Walters M, Ellsworth D (1997) From tropics to tundra: global convergence in plant functioning. Proc Natl Acad Sci USA 94:13730-13734. https://doi.org/10.1073/pnas.94.25.13730

Rennenberg H, Wildhagen H, Ehlting B (2010) Nitrogen nutrition of poplar trees. Plant Biol 12:275-291. https://doi.org/10.1111/j. 1438-8677.2009.00309.x

Ryan MG, Binkley D, Fownes JH (1997) Age-related decline in forest productivity: pattern and process. Adv Ecol Res 27:213-262. https://doi.org/10.1016/S00065-2504(08)60009-4

Ryan MG, Gower ST, Hubbard RM et al (1995) Woody tissue maintenance respiration of four conifers in contrasting climates. Oecologia 101:133-140. https://doi.org/10.1007/BF00317276

Saulnier TP, Reekie EG (1995) Effects of reproduction on nitrogen allocation and carbon gain in Oenothera biennis. J Ecol 83:23-29. https://doi.org/10.2307/2261147

Simon J, Waldhecker P, Brüggemann N et al (2010) Competition for nitrogen sources between European beech (Fagus sylvatica) and sycamore maple (Acer pseudoplatanus) seedlings. Plant Biol 12:453-458. https://doi.org/10.1111/j.1438-8677.2009.00225.x

Simon J, Dannenmann M, Gasche R et al (2011) Competition for nitrogen between adult European beech and its offspring is reduced by avoidance strategy. For Ecol Manag 252:105-114. https://doi.org/ 10.1016/j.foreco.2011.01.035
Simon J, Dannenmann M, Pena R et al (2017) Nitrogen nutrition of beech forests in a changing climate: importance of plant-soilmicrobe water, carbon, and nitrogen interactions. Plant Soil 148:89-114. https://doi.org/10.1007/s11104-017-3293-y

Simon J, Li X, Rennenberg H (2014) Competition for nitrogen between European beech and sycamore maple shifts in favour of beech with decreasing light availability. Tree Physiol 34:49-60. https:// doi.org/10.1105/tpc.114.125849

Staska B, Essl F, Samimi C (2014) Density and age of invasive Robinia pseudoacacia modulate its impact on floodplain forests. Basic Appl Ecol 15:551-558. https://doi.org/10.1016/j.baae.2014.07. 010

Stoelken G, Simon J, Ehlting B et al (2010) The presence of amino acids affects inorganic $\mathrm{N}$ uptake in non-mycorrhizal seedlings of European beech (Fagus sylvatica). Tree Physiol 30:1118-1128. https://doi.org/10.1093/treephys/tpq050

Sun Z, Liu L, Peng S et al (2016) Age-related modulation of the nitrogen resorption efficiency response to growth requirements and soil nitrogen availability in a temperate pine plantation. Ecosyst 19:698-709. https://doi.org/10.1007/s10021-0169962-5

Tagliavini M, Quartieri M, Millard P (1997) Remobilised nitrogen and root uptake of nitrate for spring leaf growth, flowers and developing fruits of pear (Pyrus communis L.) trees. Plant Soil 196:137142. https://doi.org/10.1023/A:1004207918453

Wang H, Wang W, Chang SX (2017) Sampling method and tree-age affect soil organic $\mathrm{C}$ and $\mathrm{N}$ contents in larch plantations. Forests 8:28. https://doi.org/10.3390/f8010028

Publisher's Note Springer Nature remains neutral with regard to jurisdictional claims in published maps and institutional affiliations. 